\title{
Formation of free and bound 3-monochloropropane-1,2-diol in fat-rich cereal model systems: the impact of flour composition
}

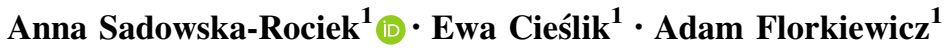

Received: 2 July 2017/Accepted: 21 September 2017/Published online: 4 October 2017

(c) The Author(s) 2017. This article is an open access publication

\begin{abstract}
The formation of 3-monochloropropano-1,2-diol (3-MCPD) and its esters in seven fat-rich cereal food model systems was investigated. The models, consisting of triolein, various cereal or pseudocereal flours (buckwheat, corn, millet, oat, rice, wheat, and starch), sugar, $\mathrm{NaCl}$ and water, were subjected to thermal processing for $10 \mathrm{~min}$ at $200{ }^{\circ} \mathrm{C}$ and then analysed in terms of the formation of the contaminants. The highest free 3-MCPD level was reached for the model with buckwheat flour $\left(90.7 \mu \mathrm{g} \mathrm{kg}^{-1}\right)$, and the lowest for the starch-containing model (control; $64.6 \mu \mathrm{g} \mathrm{kg}^{-1}$ ). For 3-MCPD esters, the content ranged from $924 \mu \mathrm{g} \mathrm{kg}^{-1}$ (starch) to $1145 \mu \mathrm{g} \mathrm{kg}^{-1}$ (oat flour). The experiment revealed the substantial influence of
\end{abstract}

protein and some minerals $(\mathrm{Mg}, \mathrm{Fe}, \mathrm{Cu}, \mathrm{Zn})$ on the level of free 3-MCPD. In the case of 3-MCPD esters, high fat content in samples promoted ester formation, but an inhibitory effect of $\mathrm{Na}$ was also observed. The promoting $(\mathrm{Mg}$, $\mathrm{Fe}, \mathrm{Cu}$ ) or inhibiting $(\mathrm{Na})$ role of minerals on 3-MCPD formation was also confirmed with the use of metal ion solutions in different concentrations. The outcomes of the experiment suggest that the use of mineral-rich flours, such as buckwheat and oat flours in heat treatment together with lipids, may lead to increased formation of 3-MCPD and its esters.
Anna Sadowska-Rociek

a.sadowska-rociek@ur.krakow.pl

1 Faculty of Food Technology, Malopolska Centre of Food Monitoring, University of Agriculture in Krakow, Balicka 122 Str, 30-149 Krakow, Poland 


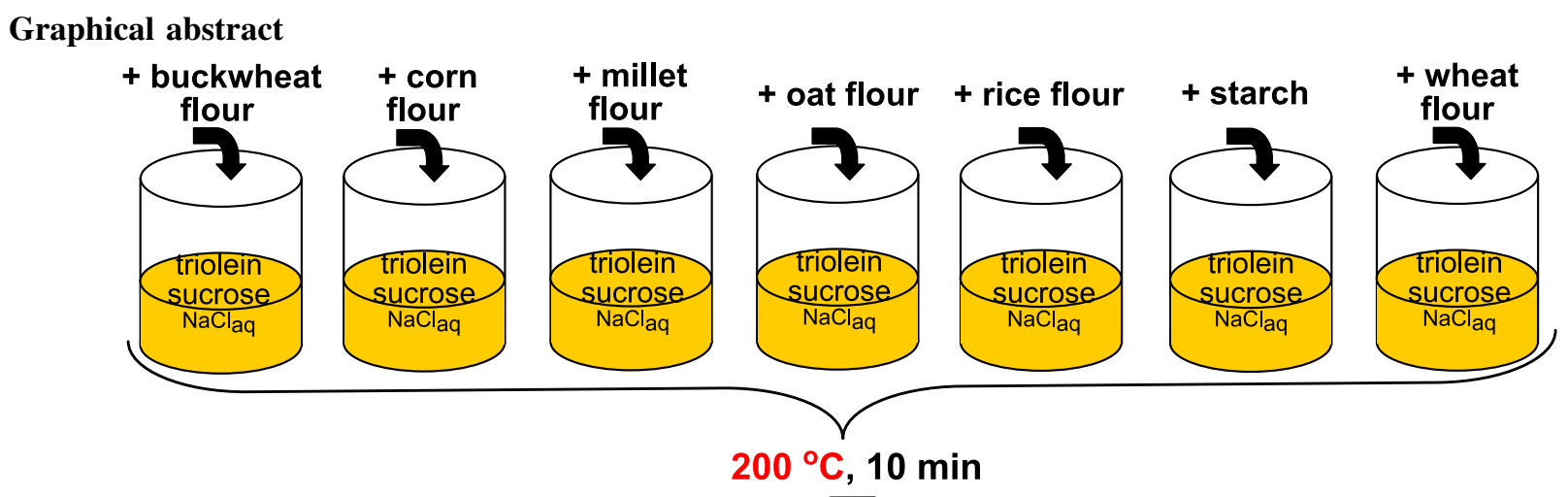

Free 3-MCPD:
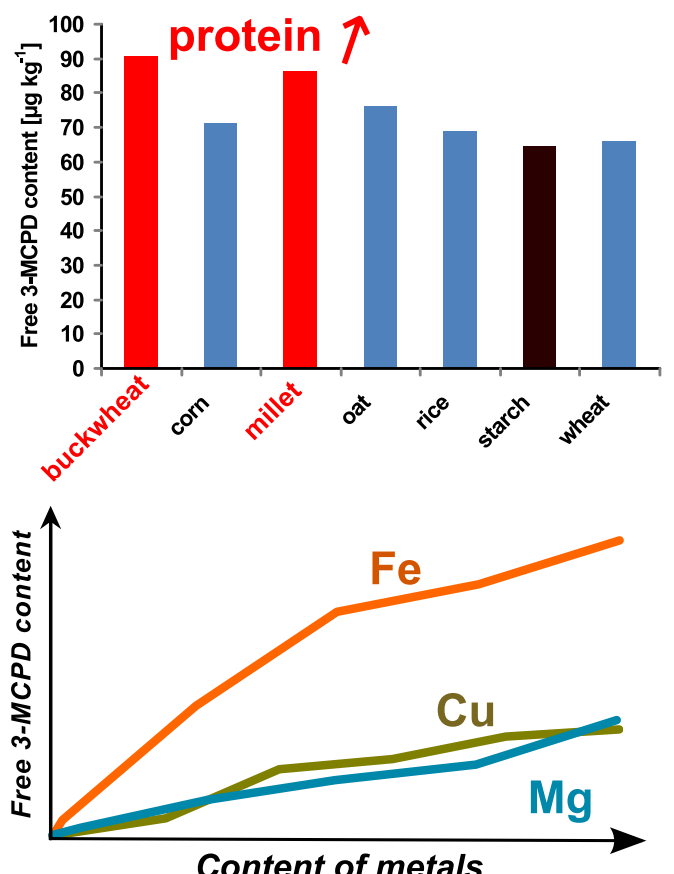

Keywords 3-Monochloropropane-1,2-diol · 3-MCPD esters $\cdot$ Cereals $\cdot$ Mineral composition

\section{Introduction}

Thermal treatment of food containing lipids, certain amino acids, and sugars processed at temperatures above $160{ }^{\circ} \mathrm{C}$ may lead to the formation of many toxic compounds such as acrylamide, furan, and a new born class of thermal processing contaminants-3-monochloropropane-1,2-diol (3-MCPD) and its fatty acid esters (3-MCPDE, e.g. 1,2-bispalmitoyl-3-chloropropanediol, 1,2-distearoyl-3-chloropropanediol, 1,2-dioleoyl-3-chloropropanediol) (Studer et al. 2004; Baer et al. 2010; Hamlet et al. 2011). Free 3 -MCPD is a potential carcinogen (Group 2B) that affects
3-MCPD esters:
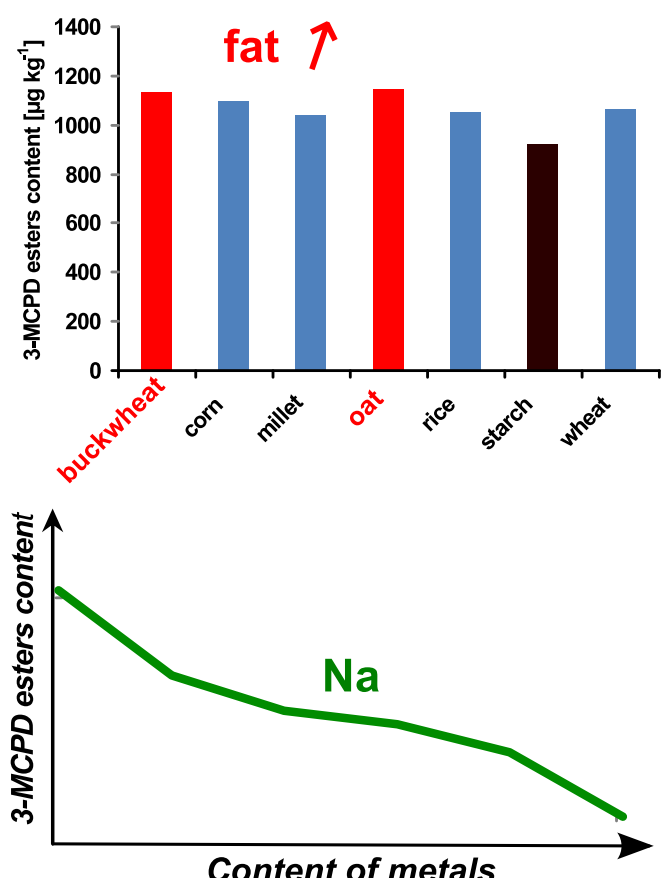

kidneys, male fertility and renal function (IARC 2012). In the case of chloropropanol esters, they have been shown to undergo complete decomposition in human digestive tract to free chloropropanols (Abraham et al. 2013). Therefore, a great interest is posed to explain the mechanism of its formation in foods.

Generally, 3-MCPD and its esters are produced in the reactions of monoacyl (MAG), diacyl (DAG) and triacyl (TAG) glycerol or free glycerol with chloride ions (present naturally or added). The levels of the compounds increase exponentially with temperature up to the maximum (about $220{ }^{\circ} \mathrm{C}$ ). Low ( $1 \%$ up to $15 \%$ ) moisture also promotes 3-MCPDE production (Hamlet et al. 2003; EFSA 2016). The formation of 3-MCPDE is associated mainly with the processes of oil refining (Craft et al. 2012; Li et al. 2016), but it has been noted that thermal processing of other food 
products may be also a significant source of these esters (EFSA 2016).

Apart from the influence of fat content, temperature, water and $\mathrm{NaCl}$ amount, many other components present in food may contribute to the formation of these compounds during heat treatment. It was also reported that sugar promoted the production of 3-MCPD by lowering the $\mathrm{pH}$ level by organic acids formed by the thermal decomposition of glucose (Hamlet and Sadd 2005), which was also confirmed in our previous studies (Sadowska-Rociek et al. 2017). Amino acids have the potential to decompose 3-MCPD or to inhibit its generation (Velíšek et al. 2003; Hamlet and Sadd 2005). However, it has been also found that the presence of amino acids may enhance the ability of sodium chloride to chlorinate glycerol, which results in free 3-MCPD formation (Hamlet et al. 2011; Rahn et al. 2015). More recently, studies concerning the formation of 3-MCPD esters reported that certain metal ions, particularly metal ions with higher catalytic capacities such as $\mathrm{Fe}^{3+}$, could significantly promote the formation of 3-MCPD esters ( $\mathrm{Li}$ et al. 2016).

Although the impact of fat, protein, water and salt on the generation of 3-MCPD and its esters in food have been already examined, there is a gap concerning the influence of other food components such as selected micro- and macro-elements on the formation of these contaminants. Therefore, considering that cereals and pseudocereals are a valuable source of certain minerals, and cereal products are often linked with the high level of fat, e.g. in bakery products (pastry goods, cookies, etc.), we decided to investigate the effects of the use of various flours and its mineral composition on the formation of 3-MCPD esters in fat-rich cereal-based food model systems. The experiment involved various cereal and pseudocereal flours (buckwheat, corn, millet, oat, rice, and wheat), which were characterised by a differentiated level of minerals ( $\mathrm{Na}, \mathrm{K}$, $\mathrm{Mg}, \mathrm{Cu}, \mathrm{Zn}, \mathrm{Fe}, \mathrm{Mn}, \mathrm{Ca}, \mathrm{P})$. Based on the results obtained from the cereal model experiment, we also investigated the influence of selected mineral content on the 3-MCPD and its esters' formation in glycerol model systems.

\section{Experimental}

\section{Materials}

Hexane and acetonitrile, grade for liquid chromatography LiChrosolv, Certipur ${ }^{\circledR}$ standard solutions of metals (sodium, potassium, calcium, magnesium, manganese, zinc, copper and iron) and buffer solutions for atomic absorption spectroscopy (cesium chloride-lanthanum chloride, cesium chloride-aluminium nitrate) were purchased from Merck (Darmstadt, Germany). Methanol, tetrahydrofuran, acetone, sulphuric acid
(98\%), hydrochloric acid, sodium chloride, glycerol, potassium hydroxide, sodium hydrogen carbonate, and saccharose were purchased from Chempur (Piekary Śląskie, Poland). Primary secondary amine (PSA) and octadecyl $\left(\mathrm{C}_{18}\right)$ solidphase extraction (SPE) bulk sorbent were supplied by Agilent Technologies (Santa Clara, California, USA). Glyceryl trioleate (triolein), ascorbic acid, sodium molybdate, potassium dihydrogen phosphate, HEPES buffer [4-(2-hydroxyethyl)-1piperazineethanesulfonic acid], Tween 80 (polyoxyethylene sorbitan monooleate), 3-monochloropropane-1,2-diol (3MCPD), 3-monochloropropane-1,2-diol-d $\mathrm{d}_{5}$ (3-MCPD- $\left.\mathrm{d}_{5}\right)$ (surrogate standard), and phenylboronic acid (PBA) (derivatisation agent) were obtained from Sigma-Aldrich (Saint Louis, Missouri, USA). 1,2-Bis-palmitoyl-3-chloropropanediol (PP-3-MCPD) and 1,2-bis-palmitoyl-3-chloropropanediol- $\mathrm{d}_{5}$ (PP-3-MCPD- $\mathrm{d}_{5}$ ) were obtained from LGC Standards (Teddington, United Kingdom) and Leco Dry (infusorial soil) was from Leco (St. Joseph, Missouri, USA). All reagents were at least of analytical purity. Sodium chloride solution of $200 \mathrm{mg} \mathrm{mL}^{-1}$ (20\%) and saturated solution of sodium hydrogen carbonate were prepared in deionised water. Intermediate and working standard solutions of chloropropanols at a concentration of $2 \mu \mathrm{g} \mathrm{mL}^{-1}$ were prepared in a $20 \% \mathrm{NaCl}$ solution. A PBA solution was prepared by dissolving $5 \mathrm{~g}$ of PBA in a $20 \mathrm{~mL}$ mixture of acetone and water $(19: 1, \mathrm{v} / \mathrm{v})$.

Six selected flours (buckwheat, millet, oat, wheat, rice, corn) and starch (control) were purchased from a local market.

\section{Analysis of flour composition}

\section{Protein content}

The protein determination in flours was assessed by Dumas method (PN-EN ISO 16634-2 2016) using TruSpec N (LECO, St. Joseph, Missouri, USA).

\section{Fat content}

The extraction and determination of fat in flours were conducted using $\mathrm{CO}_{2}$ in supercritical phase according to the previously developed procedure (Domagała et al. 2010). $0.5 \mathrm{~g}$ of flour sample was mixed with about $1 \mathrm{~g}$ of Leco Dry and placed in a metal tube between two layers of clean Leco Dry (12 cm length and $10 \mathrm{~mm}$ diameter) for extraction. The tube was placed in a TFE 2000 (LECO, St. Joseph, Missouri, USA) and extraction of fat using $\mathrm{CO}_{2}$ with a purity of 4.5 was performed. The temperature of the sample was $100{ }^{\circ} \mathrm{C}, \mathrm{CO}_{2}$ pressure was about $62 \mathrm{MPa}$ with a flow rate of $2 \mathrm{~L} \mathrm{~min}^{-1}$ (calculated on $\mathrm{CO}_{2}$ after decompression), and the static and dynamic extraction times were 15 and $35 \mathrm{~min}$. Extracted fat was collected in Eppendorf vials. 


\section{Analysis of mineral content in flours}

Selected metals (calcium, magnesium, potassium, and sodium) in the examined flours were analysed by flame atomic absorption spectrometric method (Varian AA240FS, Agilent Technologies, Santa Clara, California, USA), according to PN-EN 15505 (2009). Iron, zinc, manganese and copper were analysed according to PN-EN 14084 (2004). Phosphorous content was estimated by dry ashing followed by UV-Vis spectrophotometry according to AOAC Official Method 995.11 (Association of Official Analytical Chemists 1998) using a Cary 50 UV-Vis spectrophotometer (Agilent Technologies, Santa Clara, California, USA).

\section{Model experiment}

With the use of appropriate ingredients (Table 1), seven groups of models were prepared with four instances of each. The composition of fat-rich cereal model systems was based on typical ingredients of this type of products such as shortbread dough (Stewart and Tamaki 1992) according to a standard recipe (Miśkiewicz et al. 2012), but we focused only on the main dough ingredients (various flours, fat, sugar), omitting less important ingredients (such as eggs). To simplify the models, margarine was replaced with triolein, but a quantity of $\mathrm{NaCl}$ similar to that present in bakery fat was added to the model systems. An emulsifier (Tween 80) was added to the ingredients to make a dispersed system of these immiscible substances. The mixture also contained water in an amount comparable to real products (Stewart and Tamaki 1992). All ingredients were thoroughly mixed in glass vials that were sealed with screws, vortexed (MS1 Minishaker; IKA, Koningwinter, Germany) for $1 \mathrm{~min}$, and heated (without screws) in an oven at $200{ }^{\circ} \mathrm{C}$ for $10 \mathrm{~min}$. After heating, the vials were screwed and cooled to room temperature.

To explore the impact of selected metals on 3-MCPD formation from the basic precursors (glycerol and chloride ions), two other model systems were used. The first ("glycerol model system") was composed only of glycerol, sucrose, water and salt, with the addition of metal ions (see "Influence of selected minerals" section, in "Results and discussion"), while the other ("triolein model system") contained triolein instead of glycerol. All systems contained HEPES buffer ( $\mathrm{pH}$ 7.0) to stabilise the $\mathrm{pH}$ of the mixture and eliminate the impact of $\mathrm{pH}$ changes on the amount of 3-MCPD produced. All ingredients were thoroughly mixed in glass vials and subjected to thermal processing as described above.

\section{Free 3-MCPD determination}

$100 \mu \mathrm{L}$ of the surrogate standard solution was added to each vial. $5 \mathrm{~mL}$ of acetonitrile was added to the vial, which was vortexed for $1 \mathrm{~min}$ and the supernatant was transferred to a 50-mL PP (polypropylene) tube. The vial was rinsed again with another $5 \mathrm{~mL}$ of acetonitrile, then with two portions $(2.5 \mathrm{~mL}$ each) of water and the supernatants were also transferred to PP tube. The volume of resulted acetonitrile-water extract was approximately $15 \mathrm{~mL}$. The next steps of the analytical process, including the clean-up step, derivatisation with PBA, and the final determination of GC-MS, were performed according to a procedure previously developed and validated (Sadowska-Rociek et al. 2016) that uses chromatography coupled to mass spectrometry (GC-MS) (Varian 4000 GC-MS, Agilent Technologies, USA).

\section{Determination of 3-MCPD esters}

Determination of 3-MCPD esters in extracted fat via acid transesterification was performed according to Ermacora and Hrncirik (2012) with some slight improvements. This involved (1) a novel approach in the fat extraction from the samples; (2) the use of $\mathrm{NaCl}$ solution instead of $\mathrm{Na}_{2} \mathrm{SO}_{4}$ solution during the clean-up step of extracts after transesterification. The latter modification was due to almost two times higher GC-MS sensitivity of analyte signal in $\mathrm{NaCl}$ solution compared to the sulphate solution (based on

Table 1 Composition of model systems

\begin{tabular}{|c|c|c|c|}
\hline \multirow[t]{2}{*}{ Component } & \multicolumn{3}{|l|}{ Content/(mg) } \\
\hline & Fat-rich cereal model system & Glycerol model system & Triolein model system \\
\hline Flour (buckwheat/corn/millet/oat/rice/starch/wheat) & 380 & - & - \\
\hline Triolein & 250 & - & 250 \\
\hline Glycerol & - & 250 & - \\
\hline Sucrose & 250 & 250 & 250 \\
\hline Salt & 5 & 5 & 5 \\
\hline Water & 35 & 35 & 35 \\
\hline Tween 80 & 80 & - & - \\
\hline
\end{tabular}


preliminary study results, not shown in this work). This phenomenon resulted presumably from more effective clean-up in $\mathrm{NaCl}$ solution (high efficiency of undesirable extract components removal and lower losses of analyte). The use of $\mathrm{NaCl}$ has been also reported by Divinová et al. (2004).

\section{Fat extraction and determination}

For the extraction of fat together with 3-MCPD fatty acid esters from different food samples, a variety of solvents have been used, including $t$-butyl methyl ether or mixtures of $t$-butylmethyl ether with hexane or petroleum ether, or mixtures of hexane with diethyl ether (EFSA 2016). However, all these solvents are considered to be toxic and harmful to the environment and biota and the extraction procedure is usually time and labour consuming. Therefore, in this study we proposed a new concept that can be used for the fat extraction from food samples, which is based on the use of $\mathrm{CO}_{2}$ in supercritical phase. The extraction of fat from fat-rich cereal model systems as well as from the triolein model systems was carried out similar to the procedure presented for flours (mentioned above). Briefly, $0.5 \mathrm{~g}$ of the sample was mixed with Leco Dry reagent and placed in a metal tube that was further transferred to the fat analyser (TFE 2000, LECO, St. Joseph, Missouri, USA). Fat extraction was accomplished using $\mathrm{CO}_{2}$ in supercritical phase (sample temperature: $100^{\circ} \mathrm{C}$, $\mathrm{CO}_{2}$ pressure: $62 \mathrm{MPa}$ ). The extracted fat was further used for the determination of 3-MCPD esters.

\section{Method validation}

The fat extraction efficiency obtained by the method has been already evaluated in our previous work (Domagała et al. 2010) and the results were also confirmed through the participation in proficiency testing (QFCS 2011; QMAS 2012) with satisfactory scores. However, to confirm the usefulness of proposed procedure for the determination of 3-MCPD esters in extracted fat by $\mathrm{CO}_{2}$ in supercritical phase, the method was in-house validated in terms of linearity, limit of detection (LOD), limit of quantitation (LOQ), accuracy (recovery), and precision (repeatability and within-laboratory reproducibility) according to the guidelines established by EFSA (2016). All critical steps were thoroughly investigated before the procedure's implementation to the model systems, especially with regard to the risk of the formation of additional 3-MCPD esters during the fat extraction and $\mathrm{NaCl}$ clean-up step that could overestimate the results.

Linearity was evaluated in the range $0-11 \mathrm{mg} \mathrm{kg}^{-1}$ for 3-MCPDE (0-2072 $\mu \mathrm{g} \mathrm{kg}^{-1}$ free 3-MCPD). LOD and LOQ were calculated based on the standard deviation of the response $\left(S_{\mathrm{y}}\right)$ of the curve and the slope of the calibration curve $(S)$ at levels approximating the LOD according to the formula: $\mathrm{LOD}=3.3\left(S_{\mathrm{y}} / S\right)$ and $\mathrm{LOQ}=10\left(S_{\mathrm{y}} / S\right)$. Recovery, repeatability and within-laboratory reproducibility were evaluated by analysis of spiked samples of classic shortbread biscuits (fat content $25 \%$; purchased on retail market), with PP-3-MCPD and PP-3-MCPD- $\mathrm{d}_{5}$ at the levels of $1.25,2.5$ and $5 \mathrm{mg} \mathrm{kg}^{-1}$ that were equal to 235,470 and $941 \mu_{\mathrm{g} \mathrm{kg}}^{-1}$ of free 3-MCPD (six replicates for each concentration level). Each sample was subjected to whole analytical procedure including fat extraction, transesterification, clean-up and derivatisation steps.

The obtained results showed good linearity $\left(r^{2}>0.996\right)$. For 3-MCPDE (expressed as free 3-MCPD equivalent), LOD and LOQ were 1.5 and $4.5 \mu \mathrm{g} \mathrm{kg}^{-1}$, respectively (that is equal to 6 and $18 \mu \mathrm{g} \mathrm{kg}^{-1}$ expressed in fat basis, according to the guidelines of EFSA 2016). The results of analyte recoveries (108, 103 and 93\%) for each spiking level with the RSD (relative standard deviation) lower than $4.4 \%$ (repeatability) and below $10 \%$ (within-laboratory reproducibility) confirmed the possibility of the method implementation for the determination of 3-MCPD esters in the experiment. The results also verified that there was no risk of additional formation of 3-MCPD during the fat extraction or upon the clean-up step with the use of $\mathrm{NaCl}$ solution.

\section{Determination of pH value}

$380 \mathrm{mg}$ of appropriate flour was heated in $200{ }^{\circ} \mathrm{C}$ for $10 \mathrm{~min}$. After cooling, $10 \mathrm{~mL}$ of deionised water was added; the samples were vortexed for $2 \mathrm{~min}$ and filtered with a filter paper. The extracts were further used for the determination of $\mathrm{pH}$ level.

\section{Statistical analysis}

All data were expressed as the mean \pm standard deviation (SD). Differences between means were determined with a one-way ANOVA and Tukey's test, using Statistica 12.0 software (StatSoft, Tulsa, Oklahoma, USA). Statistical significance was declared at $p<0.05$. The correlation analysis between 3-MCPD content and selected factors was performed by calculating Pearson correlation coefficient $(r)$.

\section{Results and discussion}

\section{Flour composition}

The analysed flours contained varying amounts of protein, fat and minerals. The highest content of protein was 
observed for buckwheat and millet flours, while the lowest was in starch. The highest content of fat was observed in oat flour, the lowest in starch (not detected). Among the tested flours, buckwheat flour had the highest levels of iron, phosphorus, potassium, magnesium, copper, and zinc (Table 2). Oat flour had the highest content of manganese, but was also rich in zinc, magnesium and phosphorous, while millet had high content of copper, magnesium, iron, zinc and phosphorus. The highest levels of sodium and calcium were observed in starch. Rice flour had relatively high sodium content. The mineral content in corn flour and wheat flour was comparable, exhibiting a poor mineral profile compared to buckwheat, oat, and millet.

\section{Level of free 3-MCPD and 3-MCPD esters in fat- rich model systems}

The level of free 3-MCPD in fat-rich cereal model systems varied and was affected by the type of flour used (Table 3 ). The highest 3-MCPD level was in the buckwheat flour model $\left(90.7 \mu \mathrm{g} \mathrm{kg}^{-1}\right)$. The lowest 3-MCPD level (64.6 $\mu \mathrm{g} \mathrm{kg}^{-1}$ ) was found in the model with starch (control). The millet flour model also demonstrated a high level of free 3-MCPD $\left(86.5 \mu \mathrm{g} \mathrm{kg}^{-1}\right)$, while its level in the wheat flour and rice flour models was noticeably lower (66.1 and $68.8 \mu \mathrm{g} \mathrm{kg}^{-1}$, respectively). A post hoc test revealed three subsets: (1) buckwheat flour and millet flour; (2) corn flour and oat flour; (3) starch, wheat flour and rice flour.

The levels of 3-MCPD esters expressed as 3-MCPD were substantially higher (12-16 times) compared to free 3-MCPD. The maximum content was obtained in the model containing oat flour $\left(1145 \mu \mathrm{g} \mathrm{kg}^{-1}\right)$ and in the model with buckwheat flour $\left(1136 \mu \mathrm{g} \mathrm{kg}^{-1}\right)$. The lowest ester content was discovered once again in the control model (starch) and the model containing millet flour (924 and $1041 \mathrm{\mu g} \mathrm{kg}^{-1}$, respectively). For 3-MCPD esters, four subsets were observed: (1) buckwheat flour, corn flour and oat flour; (2) buckwheat flour, corn flour and wheat flour; (3) millet flour, rice flour and wheat flour; (4) starch.

The results of 3-MCPD level determined in the investigated model systems are generally comparable to those from other studies, conducted for samples of fat-rich, cereal models, such as shortbread cakes (biscuits). Leon et al. (2008) reported free 3-MCPD in biscuits at the ranges of $0.22-103 \mu \mathrm{g} \mathrm{kg}^{-1}$, while the free 3-MCPD contents in samples of biscuits from Polish market (Gawarska et al. 2009; Starski et al. 2013) were lower and ranged from 13 to $58.8 \mu \mathrm{g} \mathrm{kg}^{-1}$. In a study performed by Kusters et al. (2010), biscuits present in retail market had the free 3-MCPD level in the range of $8.5-40.5 \mu \mathrm{g} \mathrm{kg}^{-1}$ and 3 -MCPDE in the range of $330-1520 \mu \mathrm{g} \mathrm{kg}^{-1}$. Results of a study conducted in Hong Kong (Chung et al. 2013) showed

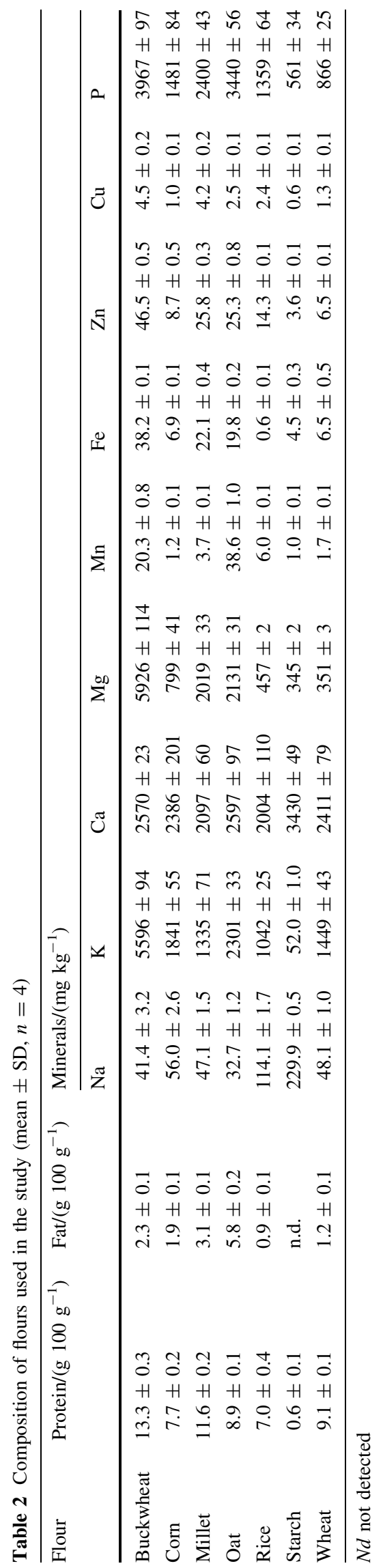


Table 3 Contents of free 3-MCPD, 3-MCPD esters (expressed as free 3-MCPD) and fat in model systems after heat treatment (mean \pm SD, $n=4$ )

\begin{tabular}{|c|c|c|c|c|c|}
\hline & Flour & 3-MCPD/( $\left.\mu \mathrm{g} \mathrm{kg}^{-1}\right)$ & 3-MCPD esters/ $\left(\mu \mathrm{g} \mathrm{kg}^{-1}\right)$ & Sample fat $/\left(\mathrm{g} 100 \mathrm{~g}^{-1}\right)$ & $\mathrm{pH}$ level of flours \\
\hline 1. & Buckwheat & $90.7 \pm 4.2^{\mathrm{a}}$ & $1136 \pm 21^{\mathrm{a}, \mathrm{b}}$ & $34.0 \pm 1.9$ & $4.97 \pm 0.05$ \\
\hline 2. & Corn & $71.0 \pm 1.8^{\mathrm{b}}$ & $1098 \pm 61^{\mathrm{a}, \mathrm{b}}$ & $30.7 \pm 1.5$ & $5.39 \pm 0.03$ \\
\hline 3. & Millet & $86.5 \pm 3.8^{\mathrm{a}}$ & $1041 \pm 20^{\mathrm{c}}$ & $26.3 \pm 1.1$ & $5.30 \pm 0.02$ \\
\hline 4. & Oat & $76.3 \pm 2.6^{\mathrm{b}}$ & $1145 \pm 26^{\mathrm{a}}$ & $36.0 \pm 1.5$ & $4.93 \pm 0.06$ \\
\hline 5. & Rice & $68.8 \pm 3.2^{\mathrm{c}}$ & $1050 \pm 51^{\mathrm{c}}$ & $24.6 \pm 2.1$ & $5.35 \pm 0.04$ \\
\hline 6. & Starch & $64.6 \pm 1.1^{\mathrm{c}}$ & $924 \pm 24^{\mathrm{d}}$ & $20.1 \pm 2.5$ & $5.95 \pm 0.06$ \\
\hline 7. & Wheat & $66.1 \pm 2.5^{\mathrm{c}}$ & $1065 \pm 31^{\mathrm{b}, \mathrm{c}}$ & $28.2 \pm 2.7$ & $5.45 \pm 0.05$ \\
\hline
\end{tabular}

Mean values with different letters in a column differ significantly $(p<0.05)$

that the level of 3-MCPDE in biscuit samples varied from 100 to $1140 \mu \mathrm{g} \mathrm{kg}^{-1}$. On the contrary, data obtained from the surveys conducted in European countries in 2009-2015 provided lower levels of these contaminants ("cookies" $200 \mu \mathrm{g} \mathrm{kg}^{-1}$ for total 3-MCPD, and "Short crusts" $154 \mu \mathrm{g} \mathrm{kg}^{-1}$ for total 3-MCPD). In 2016, the EFSA (European Food Safety Authority) decreased tolerable daily intake (TDI) level for total 3-MCPD (sum of free and bound 3-MCPD) from 2 to $0.8 \mu \mathrm{g} / \mathrm{kg}$ bodyweight. In relation to our results, assuming that the mean content of total 3-MCPD for all tested models was approximately $1140 \mu \mathrm{g} \mathrm{kg}^{-1}$, this suggests that an average man with a body weight of $60 \mathrm{~kg}$, for which calculated TDI is equal $48 \mu \mathrm{g}$, should not exceed the consumption of $42 \mathrm{~g}$ of the products.

\section{Effect of flour composition on 3-MCPD content}

To evaluate the impact of flours on the amount of free and esterified 3-MCPD generated upon heat treatment, Pearson correlation coefficients between the flour components and the contaminant levels were calculated (Table 4). As can be seen in the case of free 3-MCPD, coefficient values greater than 0.8 were obtained for protein, $\mathrm{Mg}, \mathrm{Fe}, \mathrm{Zn}$, and $\mathrm{Cu}$, while for 3-MCPD esters the absolute values of correlation coefficient higher than 0.8 were received for sample fat, $\mathrm{pH}$ and $\mathrm{Na}$ content. For the relation between the amount of 3-MCPD esters and the Na content in the flours, as well as for the relation between $\mathrm{pH}$ level and 3-MCPD ester content, the correlation coefficients were negative $(-0.89$ and -0.94 , respectively).

\section{Influence of protein and fat}

For protein and 3-MCPD (both free and bound), the correlation coefficient was 0.82 and 0.78 , respectively. However, this observation is in contradiction with our previous studies, where it has been shown that increased protein content may inhibit the formation of free 3-MCPD (Sadowska-Rociek 2017).

For 3-MCPD esters, the fat content in model systems was the most significant factor contributing to the increase of bound 3-MCPD upon heat treatment. The amount of fat extracted from the model systems after thermal processing
Table 4 Correlation coefficient $(r)$ values between free 3-MCPD/3-MCPD esters and selected model/flour parameters

\begin{tabular}{lcc}
\hline & $3-\mathrm{MCPD} /\left(\mu \mathrm{g} \mathrm{kg}^{-1}\right)$ & $3-\mathrm{MCPD}$ esters $/\left(\mu \mathrm{g} \mathrm{kg}^{-1}\right)$ \\
\hline Flour protein/(g $\left.100 \mathrm{~g}^{-1}\right)$ & 0.82 & 0.78 \\
Flour fat/(g $\left.100 \mathrm{~g}^{-1}\right)$ & 0.50 & 0.70 \\
Sample fat/(g $\left.100 \mathrm{~g}^{-1}\right)$ & 0.52 & 0.96 \\
$\mathrm{pH}$ value & -0.69 & -0.94 \\
$\mathrm{Na} /\left(\mathrm{mg} \mathrm{kg}^{-1}\right)$ & -0.56 & -0.89 \\
$\mathrm{~K} /\left(\mathrm{mg} \mathrm{kg}^{-1}\right)$ & 0.75 & 0.74 \\
$\mathrm{Ca} /\left(\mathrm{mg} \mathrm{kg}^{-1}\right)$ & -0.31 & -0.50 \\
$\mathrm{Mg} /\left(\mathrm{mg} \mathrm{kg}^{-1}\right)$ & 0.88 & 0.57 \\
$\mathrm{Mn} /\left(\mathrm{mg} \mathrm{kg}^{-1}\right)$ & 0.41 & 0.67 \\
$\mathrm{Fe} /\left(\mathrm{mg} \mathrm{kg}^{-1}\right)$ & 0.93 & 0.55 \\
$\mathrm{Zn} /\left(\mathrm{mg} \mathrm{kg}^{-1}\right)$ & 0.92 & 0.55 \\
$\mathrm{Cu} /\left(\mathrm{mg} \mathrm{kg}^{-1}\right)$ & 0.94 & 0.46 \\
$\mathrm{P} /\left(\mathrm{mg} \mathrm{kg}^{-1}\right)$ & 0.76 & 0.77 \\
\hline
\end{tabular}


was simply related to the amount of triolein added, but was also a result of the addition of flours containing various levels of fat. However, there was no strict correlation between the fat of flour origin and the amount of 3-MCPDE formed (correlation coefficient equal 0.7). The impact of the fat amount on the level of 3-MCPD esters generated has been already examined and explained, as fats are one of the precursors of esterified 3-MCPD in food (Hamlet et al. 2011, 2014; Stadler 2015).

\section{pH effect}

Low $\mathrm{pH}$ value is a valuable factor contributing to the formation of 3-MCPD and its esters in food that was also confirmed in our previous research (Sadowska-Rociek et al. 2017). For this reason, the $\mathrm{pH}$ value of the investigated flours after thermal processing was measured (Table 3). As can be observed, the lowest $\mathrm{pH}$ values were obtained for oat and buckwheat (4.93 and 4.97, respectively), and the highest was for starch (5.95). The $\mathrm{pH}$ level for the rest of the flours ranged from 5.30 to 5.45. Considering a high correlation coefficient $(-0.94)$, it has been shown that $\mathrm{pH}$ value of flours affected the 3-MCPD esters' formation in model systems. Lower $\mathrm{pH}$ values were noticed for the flours with high fat content, but besides this fact, these flours were also rich in phosphorous, which may decrease $\mathrm{pH}$ of flours. This may confirm that acidic properties of food may catalyse the reaction between lipids and chloride ions.

\section{Influence of selected minerals}

Based on the calculated correlation coefficient, the presence of $\mathrm{Mg}, \mathrm{Fe}, \mathrm{Zn}$ and $\mathrm{Cu}$ in the examined flours contributed to an increase in the level of free 3-MCPD in the studied model systems, whereas Na showed an inhibitory effect on the formation of 3-MCPD esters. Therefore, to demonstrate the possible promoting or inhibiting impact of metals present in flour on the formation of 3-MCPD, it was decided to perform a model experiment using only metal ions instead of flours. The other components of the model system (amount of triolein, sucrose, water and $\mathrm{NaCl}$ ) remained the same. However, for free 3-MCPD it was not known whether the role of metals consisted in catalysing the reaction of free glycerol with chloride ions or in catalysing the decomposition of fat with the release of free glycerol. Hence, in this case two types of model systems were prepared to clarify and explain the role of metal ions: (1) with added glycerol and (2) with added triolein. The experiment was conducted only for metals which exhibited an absolute correlation coefficient higher than 0.8 . The amount of metal content added to the model systems was established based on their content range in flours. For each
Table 5 Levels of minerals added to the glycerol and triolein models

\begin{tabular}{ll}
\hline Minerals & Levels $/\left(\mu \mathrm{g} \mathrm{kg}^{-1}\right)$ \\
\hline $\mathrm{Na}$ & $0,60,120,180,240,300$ \\
$\mathrm{Mg}$ & $0,1200,2400,3600,4800,6000$ \\
$\mathrm{Fe}$ & $0,8,16,24,32,40$ \\
$\mathrm{Zn}$ & $0,10,20,30,40,50$ \\
$\mathrm{Cu}$ & $0,1,2,3,4,5$ \\
\hline
\end{tabular}

metal, six different levels in four replicates were established (Table 5). The effect of the experiment is presented in Fig. 1.

\section{Glycerol and triolein model experiments}

In the model with added glycerol, the increasing amounts of $\mathrm{Fe}, \mathrm{Mg}$, and $\mathrm{Cu}$ promoted the formation of free 3-MCPD (Fig. 1, Ia, IIa, Va), while the addition of $\mathrm{Na}$ led to a decrease in its generation (IIIa). The addition of Zn (IVa) did not affect the formation of free 3-MCPD. For trioleincontaining models, the promoting effect of $\mathrm{Fe}, \mathrm{Mg}, \mathrm{Na}$ and $\mathrm{Cu}$ (Ib, IIb, IIIb and $\mathrm{Vb}$ ) on the formation of free 3-MCPD has been shown and, as previously seen, there was no effect for $\mathrm{Zn}$ (IVb). For the same fat-rich model systems, the amount of 3-MCPD esters increased only with increasing amounts of $\mathrm{Cu}(\mathrm{Vc})$, while the increase in $\mathrm{Na}$ content resulted in lower levels of bound 3-MCPD (IIIc). Other metals $(\mathrm{Fe}, \mathrm{Mg}, \mathrm{Zn})$ did not influence the formation of 3-MCPD esters (Ic, IIc, IVc).

Comparing the effects of metal ions on the formation of free 3-MCPD in glycerol and triolein model systems (slope of the regression line fitted to the experimental points, Fig. 1, bold values), it was noted that in the case of $\mathrm{Fe}$ the increase in metal ion content contributed to a faster increase in free 3-MCPD for the glycerol model, while for $\mathrm{Cu}$, higher levels of free 3-MCPD were produced in the system containing triolein. For $\mathrm{Mg}$, the results obtained from both model systems were comparable. Thus, it can be assumed that the roles of $\mathrm{Fe}$ is based more on catalysing the reaction between free glycerol with $\mathrm{Cl}$ ions, whereas $\mathrm{Cu}$ contributes to the decomposition of fat and the generation of free glycerol. The catalysing effect of $\mathrm{Cu}$ in fat degradation was confirmed by the increased formation of 3-MCPD esters. The catalytic role of trace metals such as $\mathrm{Fe}$ and $\mathrm{Cu}$ in lipid degradation has previously been observed in other research (Wassowicz et al. 2004). Some authors have also reported that Mg may be a catalyst for oxidation of fat (Kiokias et al. 2009). In the case of $\mathrm{Na}$, its role in inhibiting ester formation in flourcontaining model systems could be explained by various sample alkalinities. However, we did not notice any 


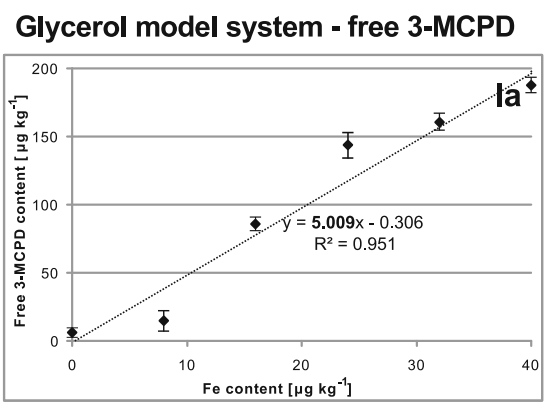

Triolein model system - free 3-MCPD
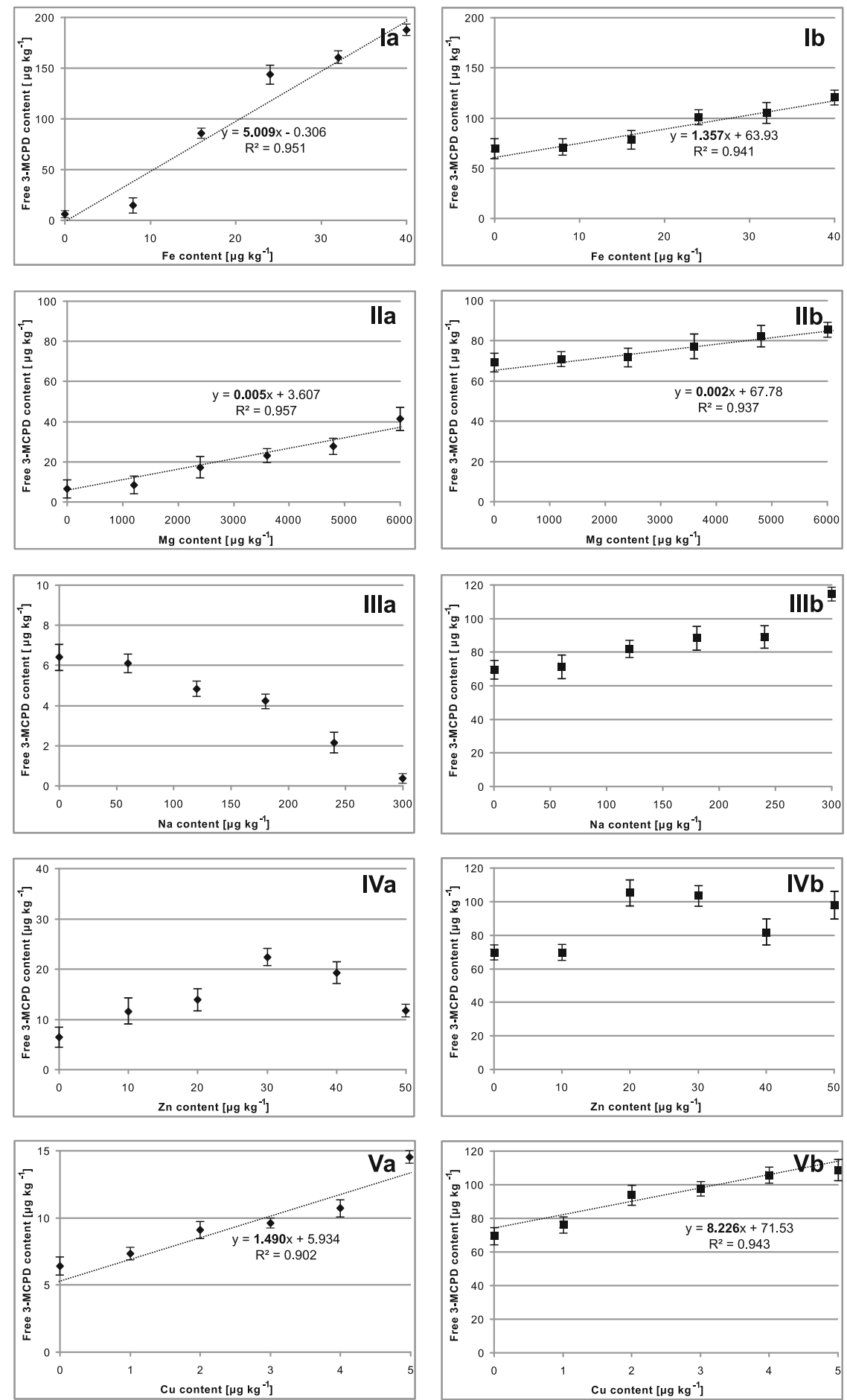
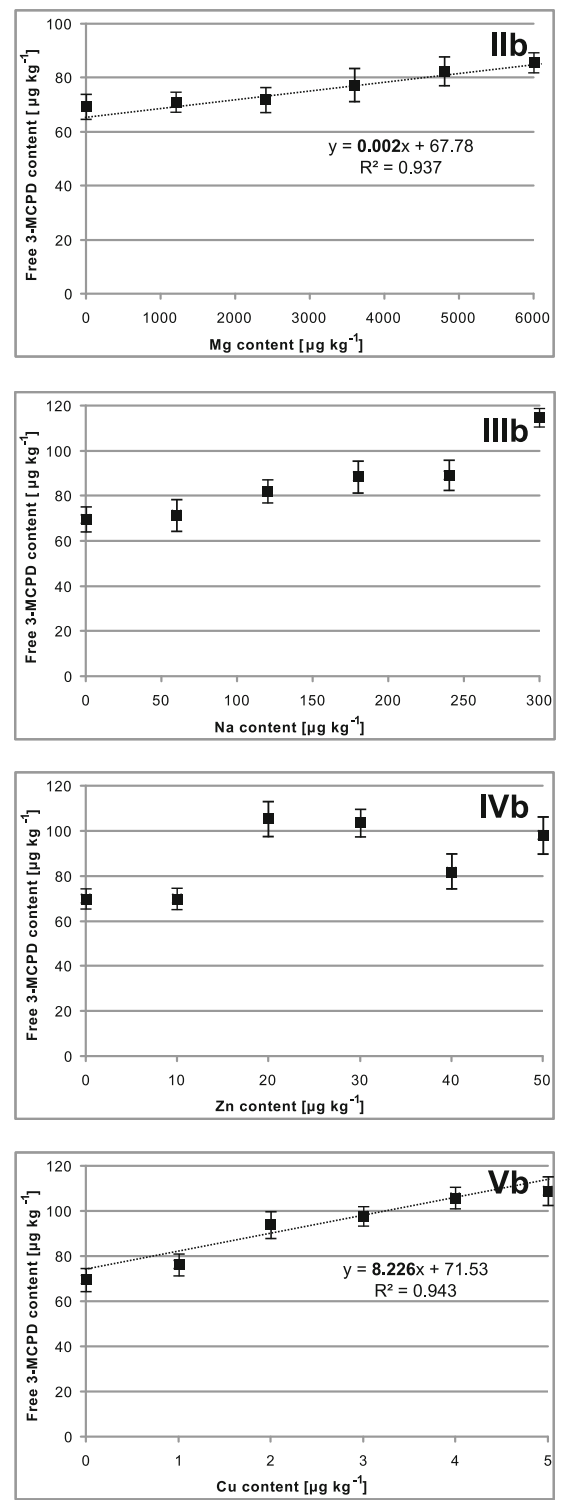

Triolein model system - bound 3-MCPD
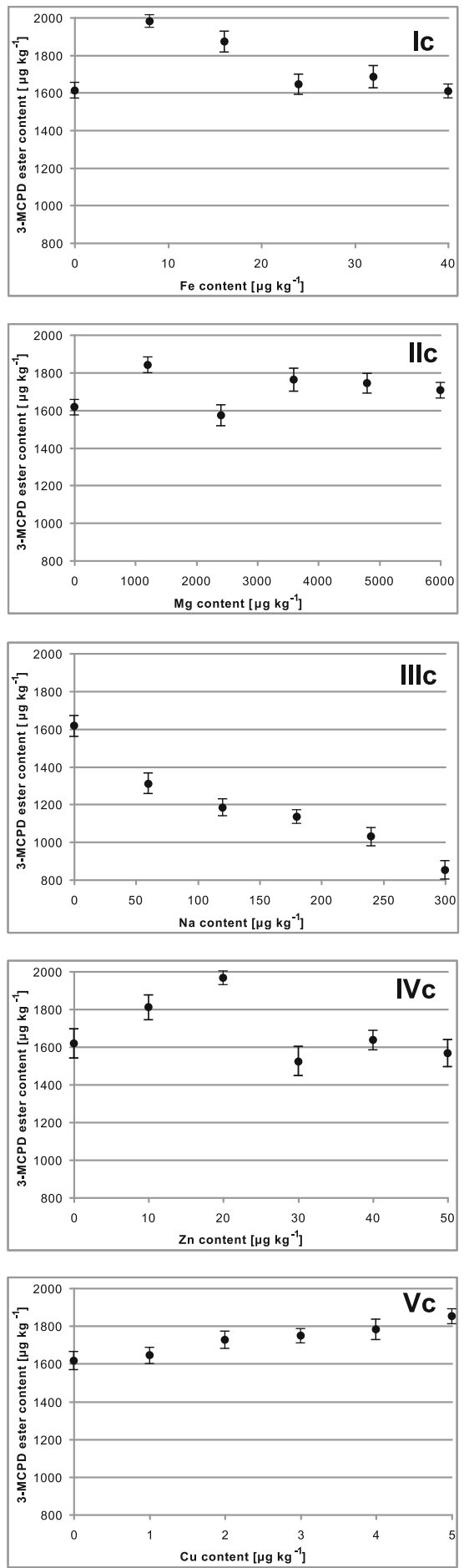

Fig. 1 Influence of metal content on free and bound 3-MCPD level in glycerol and triolein model systems

similar correlation for $\mathrm{K}$, which also had basic properties. Furthermore, in glycerol and triolein model systems the $\mathrm{pH}$ effect of the samples was excluded through the addition of buffer and the inhibiting effect of $\mathrm{Na}$ was still observed.

\section{Conclusions}

The presented study showed that the composition of flours used for the preparation of fat-rich cereal products affected 3-MCPD content in both free and bound forms. High 
protein content and the presence of some metals $(\mathrm{Mg}, \mathrm{Fe}$, $\mathrm{Cu}, \mathrm{Zn}$ ) were the main factors contributing to an elevated level of free 3-MCPD. It should be noted, however, that the amount of free 3-MCPD formed was about 10 times lower than that of esters. For the latter compounds, the most important factor influencing their formation was the fat content of the sample that was a result of not only the addition of triolein, but also of the addition of flour, mainly buckwheat and oats, which had a higher fat content. Additionally, in the case of 3-MCPD esters, an inhibiting role of $\mathrm{Na}$ was observed. The metal enhancement $(\mathrm{Mg}, \mathrm{Fe}$, $\mathrm{Cu}$ ) or suppression $(\mathrm{Na})$ was also confirmed with the use of metal ion solutions in different concentrations.

These findings are particularly important in the case of thermal processing of foods containing lipids together with fat- and mineral-rich flours, because this may lead to increased formation of free and bound 3-MCPD. Nonetheless, it should also be remembered that the formation of these contaminants is influenced by several factors at the same time, so all outcomes established in the research should be considered together rather than individually.

\section{Compliance with ethical standards}

Conflict of interest Anna Sadowska-Rociek, Ewa Cieślik, and Adam Florkiewicz declare that they have no conflict of interest.

Ethical approval This article does not contain any studies with human participants or animals performed by any of the authors.

Funding This study was funded by the Ministry of Science and Higher Education of Republic of Poland within the statutory R\&D activities (DS-3707/16/KTGiK).

Open Access This article is distributed under the terms of the Creative Commons Attribution 4.0 International License (http://crea tivecommons.org/licenses/by/4.0/), which permits unrestricted use, distribution, and reproduction in any medium, provided you give appropriate credit to the original author(s) and the source, provide a link to the Creative Commons license, and indicate if changes were made.

\section{References}

Abraham K, Appel KE, Berger-Preiss E, Apel E, Gerling S, Mielke H, Creutzenberg O, Lampen A (2013) Relative oral bioavailability of 3-MCPD from 3-MCPD fatty acid esters in rats. Arch Toxicol 87:649-659

Association of Official Analytical Chemists (1998) AOAC Official method 995.11. Phosphorus (total) in foods-colorimetric method. Official methods of analysis of AOAC International. AOAC International, Rockville

Baer I, De La Calle B, Taylor P (2010) 3-MCPD in food other than soy sauce or hydrolysed vegetable protein (HVP). Anal Bioanal Chem 396:443-456

Chung SWC, Chan BTP, Chung HY, Xiao Y, Ho YY (2013) Occurrence of bound 3-monochloropropan-1,2-diol content in commonly consumed foods in Hong Kong analysed by enzymatic hydrolysis and GC-MS detection. Food Addit Contam 30:1248-1254

Craft BD, Chiodini A, Garst J, Granvogl M (2012) Fatty acid esters of monochloropropanediol (MCPD) and glycidol in refined edible oils. Food Addit Contam A 23:1-6

Divinová V, Svejkovská B, Doležal M, Velíšek J (2004) Determination of free and bound 3-chloropropane-1,2-diol by gas chromatography with mass spectrometric detection using deuterated 3-chloropropane-1,2-diol as internal standard. Czech J Food Sci 22:182-189

Domagała J, Sady M, Grega T, Pustkowiak H, Florkiewicz A (2010) The influence of cheese type and fat extraction method on the content of conjugated linoleic acid. J Food Compos Anal 23:238-243

EFSA, European Food Safety Authority (2016) Risks for human health related to the presence of 3- and 2-monochloropropanediol (MCPD), and their fatty acid esters, and glycidyl fatty acid esters in food. EFSA J 4(5):4426-4585

Ermacora A, Hrncirik K (2012) Evaluation of an improved indirect method for the analysis of 3-MCPD esters based on acid transesterification. J Am Chem Soc 89:211-217

Gawarska H, Sawilska-Rautenstrauch D, Starski A, Karłowski K (2009) Occurrence of 3-monochloropropane-1,2-diol (3-MCPD) in food products. Ann Natl Inst Hyg 60:213-216

Hamlet CG, Sadd PA (2005) Effects of yeast stress and pH on 3-monochloropropanediol (3-MCPD)-producing reactions in model dough systems. Food Addit Contam A 22:616-623

Hamlet CG, Sadd PA, Gray DA (2003) Influence of composition, moisture, $\mathrm{pH}$ and temperature on the formation and decay kinetics of monochloropropanediols in wheat flour dough. Eur Food Res Technol 216:122-128

Hamlet CG, Asuncion L, Velíšek J, Doležal M, Zelinková Z, Crews C (2011) Formation and occurrence of esters of 3-chloropropane1,2-diol (3-CPD) in foods: what we know and what we assume. Eur J Lipid Sci Technol 113:279-303

Hamlet CG, Asuncion L, Velíšek J, Doležal M, Zelinková Z, Crews C, Anderson W, Pye C (2014) Investigation of the formation of 3-chloropropane-1-2-diol (3-MCPD) from mono- and di-esters of its fatty acids in foods. Raport of the projects FS231006. FS231074. FS231075. Food Standard Agency, London

IARC, International Agency for Research on Cancer (2012) 3-monochloro-1,2-propanediol. Monographs on the evaluation of carcinogenic risks to humans. Some chemicals present in industrial and consumer products, food and drinking-water, vol 101. IARC, Lyon, pp 349-374

Kiokias S, Varzakas TH, Arvanitoyannis IS, Labropoulos AE (2009) Lipid oxidation and control of oxidation. In: Yildiz F (ed) Advances in food biochemistry. CRC Press, Boca Raton, pp 383-408

Kusters M, Bimber U, Ossenbruggen A, Reeser S, Gallitzendorfer R, Gerhartz M (2010) Rapid and simple micromethod for the simultaneous determination of 3-MCPD and 3-MCPD esters in different foodstuffs. J Agric Food Chem 58:6570-6577

Leon N, Yusa V, Pardo O, Pastor A (2008) Determination of 3-MCPD by GC-MS/MS with PTV-LV injector used for a survey of Spanish foodstuffs. Talanta 75:824-831

Li C, Zhou Y, Zhu J, Wang S, Nie S, Xie M (2016) Formation of 3-chloropropane-1,2-diol esters in model systems simulating thermal processing of edible oil. Food Sci Technol 69:586-592

Miśkiewicz K, Nebesny E, Oracz J (2012) Formation of acrylamide during baking of shortcrust cookies derived from various flours. Czech J Food Sci 30:53-66

PN (2004) EN 14084:2004 Foodstuffs-determination of trace elements-determination of lead, cadmium, zinc, copper and 
iron by atomic absorption spectrometry (AAS) after microwave digestion

PN (2009) EN 15505:2009 Foodstuffs-determination of trace elements - determination of sodium and magnesium by flame atomic absorption spectrometry (AAS) after microwave digestion

PN-EN (2016) ISO 16634-2:2016-08 Food products-determination of the total nitrogen content by combustion according to the Dumas principle and calculation of the crude protein contentPart 2: cereals, pulses and milled cereal products

Rahn A, Varoujan KK, Yaylayan A (2015) Mechanism of chemical activation of sodium chloride in the presence of amino acids. Food Chem 166:301-308

Sadowska-Rociek A (2017) Impact of spices addition on 3-monochloropropane-1,2-diol formation in shortbread and cracker model systems. J Food Nutr Res 1:1-9

Sadowska-Rociek A, Cieślik E, Sieja K (2016) Simultaneous sample preparation method for determination of 3-monochloropropane1,2-diol and polycyclic aromatic hydrocarbons in different foodstuffs. Food Anal Methods 9:2906-2916

Sadowska-Rociek A, Cieślik E and Sieja K (2017) Mitigation role of erythritol and xylitol in the formation of 3-monochloropropane1,2-diol and its esters in glycerol and shortbread model systems.
European Food Research and Technology. Epub ahead of print 24 May 2017. DOI:10.1007/s00217-017-2916-0

Stadler RH (2015) Monochloropropane-1,2-diol esters (MCPDEs) and glycidyl esters (GEs): an update. Curr Opin Food Sci 6:12-18

Starski A, Jedra M, Gawarska H, Postupolski J (2013) Assessing exposure to 3-MCPD from bakery products based on monitoring studies undertaken throughout Poland. Ann Natl Inst Hyg 64:277-283

Stewart JE, Tamaki JA (1992) Agriculture Handbook No 8-18: Composition of Foods - Baked Products. Nutrition Monitoring Division, Human Nutrition Information Service, USDA Superintendent of Documents. US Government Printing Office, Washington

Studer A, Blank I, Stadler RH (2004) Thermal processing contaminants in foodstuffs and potential strategies of control. Czech $\mathbf{J}$ Food Sci 22:1-88

Velíšek J, Calta P, Crews C, Hasnip S, Doležal M (2003) 3-Chloropropane-1,2-diol in models simulating processed foods: precursors and agents causing its decomposition. Czech J Food Sci 21:153-161

Wąsowicz E, Gramza A, Hęś M et al (2004) Oxidation of lipids in food. Pol J Food Nutr Sci 13:87-100 